\title{
On the culturology Language of human body parts in Vietnamese and English
}

\author{
Nguyen Van Hai \\ Department of Linguistics, HCMC Institute of Formation and Promotion, Hochiminh city, Vietnam
}

Email address:

tiensihai@yahoo.com,ifphcm@gmail.com

\section{To cite this article:}

Nguyen Van Hai. On the Culturology Language of Human Body Parts in Vietnamese and English. International Journal of Language and Linguistics. Vol. 2, No. 6, 2014, pp. 368-373. doi: 10.11648/j.ij11.20140206.15

\begin{abstract}
The study on the words related to body parts has been an interesting topic for research in linguistics. This is also the case in Vietnamese language. The case is even becoming more interesting when we compare two languages with different cultures. In this paper, we analyze the words related to body parts in Vietnamese and in English. The words analyzed are the words "đầu" and "chân" in Vietnamese and their English equivalents "head" and "foot/leg", respectively. The analysis started from the point of view of culturology language that relates the words with the cultural phenomenon. Particularly, the analysis focuses on the transfer meanings shown in the metaphors and metonymys. The discussion is concluded with the calculation on the statistical relations between the words "đầu" and "chân" in Vietnamese and the words "head" and "foot/leg" in English based on the corpora available in the Sketch Engine. The results show that the relation between body parts in Vietnamese is closer that the relation between the body parts in English.
\end{abstract}

Keywords: Culturology Language, Corpus Linguistics, Vietnamese, English

\section{Introduction}

There have been some studies on words referring to human body parts in Vietnamese. For example, Duc Hien Trinh et al. examine them as the elements in the compound [8], whereas Khac Viet Bui studies their symbolism [2]. Other authors also studied elements of idioms mentioning human body parts, e.g. Thi Thu Nguyen [7] survey the cultural nature of the Vietnamese idioms that contain words of human's four limbs (139 idioms have the word "tay -(hand)", 100 have the word "chân - (foot)". However, there is still a room for further research on the culturology of human body parts, especially when we want to compare the terms used in two languages, with different cultural backgrounds.

This paper analyzes the culturology language of human body parts in Vietnamese and English. The study focuses on the words "đầu" and "chân" in Vietnamese and their English equivalents "head" and "foot/leg", respectively. This study is expected to point out the specific characteristics of ethnic nature of the cognitive reality "đầu-chân" in comparison with "head-foot/leg", expressed through identification, transferred meanings and the text content. The relation between one word and another is also shown by using the sketches of the words related to body parts based on the corpus linguistics point of view, in order to better explain the statistical relations between the body parts.

\section{The Culturology Language}

The culturology language is a branch of linguistics studying the cultural organization-structure language systems in all aspects and elements of the language to reflect the cultural characteristics of the community speak the language. This science explores the inter-relationship between language's specification and the ethnic cultural characteristics (Nguyen Van Chien - 2004) [3]. The cultural and ethnic characteristics are reflected in many aspects, particularly in terms of the meaning of the words and in terms of the transferred meaning and symbolic meaning.

In terms of the meaning of words, there are social-historic factors that may play a role. It is known that language is an existing form of human's social-historic experiences in general, and each ethnic group in particular. Those social-historic experiences are reflected and kept clearly within the meaning of words in languages, especially in words' symbolic meaning (i.e. in using a symbolic expression of the word). For example, in Vietnamese, "lotus" means that the "pure and noble" ("being close to mud but that does not 
stink of mud"), "cóc tía" means "gritty" ("gan cóc tía"), "red" is the lucky ("red numbers"), "belly" is the thought, deep feelings of human beings ("suy bụng ta ra bụng người" - "a man thinks other people have the same thought with him).

In terms of the transferred meanings and the symbolic meaning, the semantic structures become the influencing factors. Transferred meanings could be interpreted as a shift from type names having semantic structures to a name having other semantic structures. For instance, from the natural to the inner world of man and vice versa from the natural phenomenon to other natural phenomena, from the people and reality closer to the human world to the entire remaining objective. Obviously, in the transferred meanings, there are common points of the whole human race and the distinct of each nation. For example, on the one hand, both British and Vietnamese call the start of a path is "đầu" (head): "đầu đường" (the head of a street) và "the head of a street". On the other hand, while the Vietnamese call "đầu mùa" (head + season, i.e. the beginning of a season), there is a transfer from human's head to the beginning of a period of years, the British does not have the means of transmission of this kind, instead, they call, for example, "beginning of spring" ("the beginning of spring"). In association with the transferred meanings, there is the phenomenon of symbolism. This meaning of the language's symbols will appear when its reference relationship has the reason, leading people to reckon a new meaning, being different from its original meaning. The inter-association happens in the own way of an ethnic group. For example, while for the Russian, the word "Medved" ("bear") symbolizes "the laggards", the word "bear" in Vietnamese, is connected to "sassy and aggressive guys", "sassy personality, violent": "You are bear!", "You look so like a bear". For Vietnamese, "liễu yếu đào tơ" (silk willow, weak peach) represents young, rail and slender woman. Moreover, "nồi đồng cối đá" (copper pot, stony mortar), symbolizes the durability of objects.

\section{Corpus Linguistics}

Svartvik [6] defined corpus linguistics as a study of language use in reality observed by collecting data from spoken or written texts as the form of actual language, analyzed by using computer (corpus software), and described under specific points of view and purposes. The data is called corpus, having a plural name of corpora. The study of corpus began when some linguists preferred explaining the nature of language by looking at its actual use to explaining through abstract knowledge of language rules.

Corpus linguistics has been helping other linguistic studies with technology and precise measurement in the analysis these recent years. Having an aim to explain language through the investigation of real life texts, many linguists nowadays use corpus-based analyses to approach their studies which are in other areas of study such as semantics, pragmatics, critical discourse analysis, stylistics, syntax, and sociolinguistics [1].

Since 1998, the study of corpus has become more flourishing as the linguists realized the usefulness of Web as a corpus. In Web, variation of language form, including the new and uncommon ones, can be easily found. Besides, the problem of costly, time-consuming, limited-sized, and dynamical study of conventional models of corpus can all be answered by Web. In this paper, the corpus of the Vietnamese language is taken from the Sketch Engine that is available in the website www.sketchengine.co.uk.

The Sketch Engine is a corpus query system (CQS) which, in addition to general CQS functions, provides 'word sketches', one-page, automatically-generated summaries of a word's grammatical and collocational behavior, and also an automatic thesaurus, and 'sketch differences', identifying the similarities and differences between the collocational behavior of two similar words [4].

The statistical calculation used in the Sketch Engine is called a $\log$ Dice. The $\log$ Dice score is chosen because it has a reasonable interpretation, scales well on a different corpus size, is stable on subcorpora, and the values are in reasonable range [5]. With the Sketch Engine, the logDice calculation is done automatically. Therefore, the results can be presented directly.

\section{Discussion}

\subsection{The Word "đầu" in Vietnamese and the Corresponding Words in English}

In Vietnamese, "đầu" means the top part of the human body or the front part of the animal's body. The Vietnamese also has different words that refer to the top part of the body, such as: "skull". The word "đầu" when it refers to a "skull" means the brain box containing bones. It is sometimes used to indicate the beginning of metonymy: "Having spent countless, his head was broken. The skull may refer to death, and it is sometimes called "the flower" (especially when it comes to burial). The "skull" is also sacred in the mind of the Vietnamese people, so they are used as the words to curse. A curse in Vietnam is considered very offensive. For example, "the skull was you flower house", is a very heavy cursing usually addressed to an enemy.

Corresponding to the word "đầu" in Vietnamese, there is the English word "head". It is also associated with many words, and with the combinations with other words, it can have different meanings, for example: headache (a pain in the head), headgear (anything worn on the head, e.g. a hat), headphones (a set of equipment worn over or in the ears to listen to music, the radio, etc.), headmaster (a school principal), etc.

The detailed comparison between the word "đầu" in Vietnamese and the word "head" in English is presented in Table 1 .

As we can see in Table 1 above, we see, by converting meaning metaphorically, basically, two words "đầu"and "head"of Vietnamese and English have many similarities (the meaning number 1-6), Although there are similarities, there are still differences. For example, while the Vietnamese expand the identification with criteria "first" for both space and time, the British stop at space dimensions only. Specifically, both Vietnamese and English will say: "the first 
in the list", "the first in the post", "first chapter" (when talking about position in space), but only the Vietnamese said: "Early Spring", "the beginning of stories", "first love"..., which is about time, first time, while the British, in this case, to express the same content, do not use the word "head", they used different words, such as: "đầu xuân" $\rightarrow$ "beginning of Spring", "đầu câu chuyện" $\rightarrow$ "beginning of the story", "mối tình đầu" $\rightarrow$ "the first love".

The difference is metaphorically transferred meaning of two English words that Vietnamese words do not have, it's "the top surface of a liquid in a container" (head of beer / milk - "đầu bia", "đầu sữa”...). (the Vietnamese said: "bọt bia", "váng sữa"); "refer to the climax stage/climax of a phenomena" (Head of trouble / crisis - while the Vietnam said: "culmination of incidents / a crisis")..

By metonymically transferred meanings, the word "đầu" in Vietnamese and the "head" in English have 4 common small differences cases (1-4). For instance, also refers to the head, while the majority of the British used the word "head", the
Vietnamese people, depending on the case use the words "đầu khoa, hiệu trưởng" (which mean dean/ head of department) (not say: "đầu trường"), thủ quân, đội trưởng (captain, captain of team) (not say: “đầu đội”), tư lệnh quân đội -commander (do not say "đầu quân"), etc....

There are three differences metonymically switched meanings of English: refer to portrait (nice colour head beautiful color portrait), refer to physiological ability, endurance of the human body (a good head of drink - have high alcohol tolerance, not cause headache or dizziness when taking much), refer to headache (have a head). Vietnamese do not use the word "đầu" with this metonymy.

By converting meaning metaphoric- metonymy, in Vietnamese there are 2 cases using the word "đầu" that the word "head" in English does not have: "đầu bài/đề" $\rightarrow$ content of articles; "đầu bài/đề"and "đầu (của) bảng danh sách" $\rightarrow$ "top of the list $\rightarrow$ quality, highest grade level $\rightarrow$ "top ginseng / phone top.

Table 1.The word "đầu" in Vietnamese and the word "head" in English

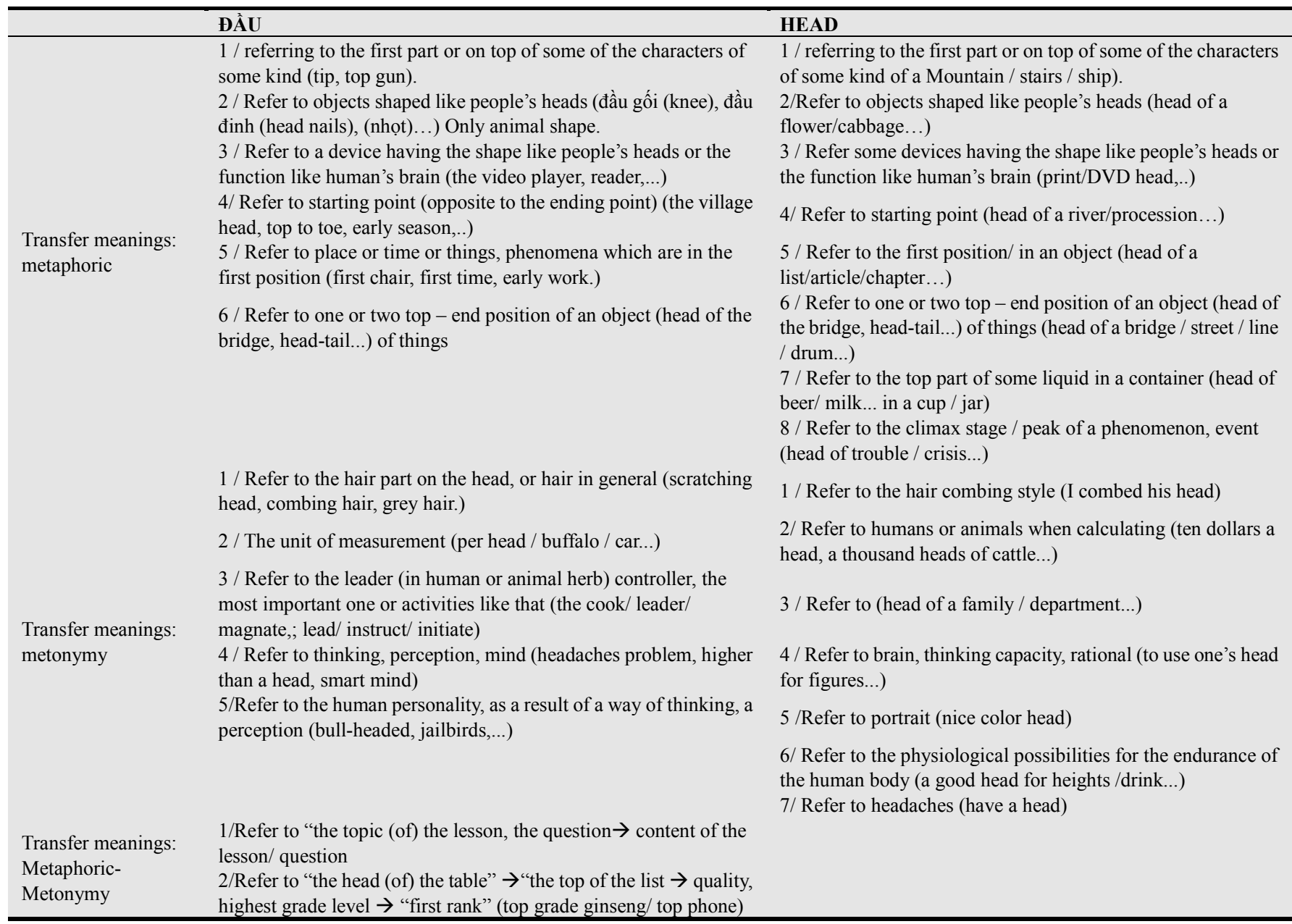

\subsection{The Word "chân" in Vietnamese and the Corresponding Words in English}

In Vietnamese, the word "chân" is used to refer to the bottom part of the human or animal body. The word "chân" may refer to continuous activities, for example: My mother is rarely off her legs, means my mother rarely has a break, which means that she is always busy. The word "chân" may also refer to an action that is tailored to a particular condition. For example: Stretch your legs according to the coverlet, means to 
stretch your legs under the sheets, which is to act in accordance with the circumstances.

The detailed comparison between the word "chân" in Vietnamese and the word "foot/leg" in English is presented in Table 2.

Table 2 shows, metaphorically, that there are similarities between the meaning number 3 and 4 of "chân" and the ways to express the word "chân" (duck boneless leg, centipede's foot path...) with the meaning number 1, 3 of the word "leg" and meaning number 1 of the word "foot". The differences are quite large in the meaning of the word "chân", "cẳng", "leg" and "foot". In particular, two words "chân" và "cẳng" in
Vietnamese do not have the meanings as following: way, route, edge of the triangle, stretch road, electric phase, device as the meaning of the word "leg". While the British used "leg" to refer to the true leg (of human, in flesh) and prostheses (wood, plastic, metal...), the Vietnamese people have added the word "fake-giả" in conjunction with "foot". The meaning numbers 3 and 4 of the word "foot" (refer to background of stratigraphy, the sediment of fluid) there is no equivalent in "chân", "cẳng" in Vietnamese. Meaning number 2 of "foot" (refer to foot of mountain, soles of shoes...) is equivalent to a part of the meaning 3 and 4 of the word "chân" in Vietnamese.

Table 2.The word "chân" in Vietnamese and the word "foot/leg" in English

\begin{tabular}{|c|c|c|}
\hline & CHÂN - LEG & LEG \\
\hline \multirow[t]{15}{*}{ Transfer meanings: metaphoric } & $\begin{array}{l}1 \text { / Refer to a quarter of four-leg animals, as a source of } \\
\text { foods (a pig is divided into } 4 \text { equal parts) }\end{array}$ & 1/ Refer to legs of insects \\
\hline & $\begin{array}{l}\text { 2/ Refer to legs of pig, including thigh and shin, nails, as } \\
\text { a food source (boiled pig's leg) }\end{array}$ & 2 / Refer to the artificial leg for the disabled. \\
\hline & $\begin{array}{l}\text { 3/Refer the bottom part of some furniture (the } \\
\text { bed/furniture, tripod / column...) }\end{array}$ & 3/ Refer to table legs, chairs, beds, wardrobes \\
\hline & $\begin{array}{l}4 \text { / Refer to the bottom portion adjacent to the surface } \\
\text { (foot mountain / wall/teeth...) }\end{array}$ & $\begin{array}{l}\text { 4/ Refer to rout (travel, tourism relay races) in sports, stage / } \\
\text { stage on orbital routes }\end{array}$ \\
\hline & CĂNG - LEG & 5/ Refer to laps, running round \\
\hline & $\begin{array}{l}\text { 1/ Refer to root or branch split at the root of some } \\
\text { plants(bamboo root / cassava...) }\end{array}$ & $\begin{array}{l}6 \text { / Refer to the edge of the triangle, edge bottom of the } \\
\text { trapezium (similarity, as "arm") }\end{array}$ \\
\hline & & $\begin{array}{l}7 / \text { Refer to the segment / of the road which is broken in several } \\
\text { sections }\end{array}$ \\
\hline & & $8 /$ Refer to the mix (of power lines, wires electric) \\
\hline & & 9 / Refer to the branches (of the device, network) \\
\hline & & FOOT \\
\hline & & 1/ Refer to animals' paws \\
\hline & & $2 /$ Refer to foothills, shoe soles, the under of the specifications \\
\hline & & 3/ The stratigraphic base (in geology) \\
\hline & & 4/ The sediment of liquids \\
\hline & CHÂN - LEG & LEG \\
\hline \multirow[t]{11}{*}{$\begin{array}{l}\text { Transfer meanings: } \\
\text { metonymy }\end{array}$} & $\begin{array}{l}1 \text { / Refer to the travel by foot of people (vui chân đi chơi } \\
\text { - people who feel happy when they go out, trú chân - } \\
\text { reside temporarily) }\end{array}$ & 1 / Refer to pig's feet as a source of food (lambs, pork, beef) \\
\hline & $\begin{array}{l}2 \text { / Refer to position, duty of a member of the an } \\
\text { organization (as a member of Council, a player in card } \\
\text { game using a deck of } 120 \text { cards and played by five } \\
\text { persons) }\end{array}$ & $2 /$ Refer to pants or socks \\
\hline & $\begin{array}{l}3 \text { / Refer to mediate, brokers work in the black affairs } \\
\text { (wooden leg) }\end{array}$ & FOOT \\
\hline & 4 / The sources supplying (the clue) & 1/ Refer to animals' foot as food \\
\hline & & $2 /$ Refer to steps \\
\hline & & 3 / Refer to gait \\
\hline & & $4 /$ refer to socks part corresponding with the feet \\
\hline & & 5/ Refer to pedestrian (footbridge) \\
\hline & & 6/ Refer to the infantry (foot soldiers) (foot and horse) \\
\hline & & $\begin{array}{l}\text { 7/ The unit of measurement for length, about a foot length, } \\
\text { over } 30 \mathrm{~cm}\end{array}$ \\
\hline & & FOOT \\
\hline Transfer meanings: & & 1 / Refer to the lower part, the end of the some animals (the \\
\hline Metaphoric- Metonymy & & $\begin{array}{l}\text { foot of a ladder / bed / table - at the end of the month /bed / } \\
\text { desk...) }\end{array}$ \\
\hline
\end{tabular}

By way of metonymy, the differences between the "chân", "leg", and "foot" are quite noticeable. In particular, "foot" and "leg" do not refer to "the daily travel activities of human "as "chân", but "foot" has the meaning that "chân" does not: refer to walk, gait, people's travel activities (pedestrians, infantry). Regarding gait, while "foot" refer to gait in general, "chân" refers to gait in a limited number ways of expressions, such as “"“dáng đi chữ bát - an strange gait, "bandy-legged". "Foot" and "leg" do not have the meanings of the position, the duties of a member of an organization, such as "foot in the Jury - as a member", "a player in card game using a deck of 120 cards and played by five persons (tổ tôm) as in the word "chân" in 
Vietnamese.

\subsection{The Statistical Relations between "đầu" and "chân", and between "head and foot/leg"}

In order to make a further and more precise comparison between the Vietnamese words and their corresponding English words, it is necessary to make a statistical calculation using a corpus of Vietnamese language. As explained previously, the calculation will be made using the LogDice statistics that is available in The Sketch Engine (Kilgarriff et al. 2004). The Sketch English contains approximately 100 million words of Vietnamese words. This is then compared with the British National Corpus, which is an English language corpus containing about 100 million words as well.

The statistical relations between "đầu" and "chân", based on the Vietnamese corpus in the Sketch Engine can be seen in Figure 1.

In Figure 1, we can see that the words "đầu" and "chân" occur together for 1142 times in the 100 million word corpus. The calculation also shows the result of 8.8 per million. To understand the significance of this number, we need to calculate the relations between the English words "head" and "leg" as well as the words "head" and "foot". Figure 2 presents the relations between the English words "head" and "leg" in the British National Corpus, whereas Figure 3 presents the relations between the words "head" and "foot".

\begin{tabular}{|c|c|c|}
\hline Page 1 & of $58 \mathrm{Go}$ & Next I Last \\
\hline 57411.txt & \multicolumn{2}{|c|}{ phát hiện được việc nào tốt ông dùng bút chi đâu đỏ gạch chân rồi điện vê địa phương có } \\
\hline 3473.txt & \multicolumn{2}{|c|}{ lớn lao, hông hùng dũng, chân lắn vào minh, đâu con nào cûng thật cân đôi , thâm thấp như } \\
\hline 41210.txt & \multicolumn{2}{|c|}{ chung quanh sẽ là đước, trước mặt là biển ; đâu đội trời chân đạp đất, nghe lặng thầm } \\
\hline 18279.txt & \multicolumn{2}{|c|}{ ngôi ở nơi đặt xác Chúa Giêsu, một vị đàng đâu, một vị đàng chân " ( Yn 20 , 11 - 12} \\
\hline \multicolumn{3}{|c|}{ 10854.txt Không thế chiên thắng bắng cách dẫm chân trên đâu trên cố người dân địa phương được. Cân } \\
\hline 45406.txt & \multicolumn{2}{|r|}{ ai là giết đâu. Rôi ngài nhin ông cậu từ đâu xuông chân, phán tiêp : óỏ Còn cậu cũng } \\
\hline 14747.txt & \multicolumn{2}{|c|}{ Hà Nội mùa này phố cũng như sông Cái rét đâu đông , chân em run ngâm trong nước lạnh } \\
\hline 14747.txt & \multicolumn{2}{|c|}{ Hà Nội mùa này phố cũng như sông Cái rét đâu đông , chân em thâm vì ngâm nước lạnh Hoa } \\
\hline 48902.txt & \multicolumn{2}{|r|}{ hình chiêu - tìm ra các góc giây là chân, đâu ... Ngày nay có rất nhiêu tài liệu hướng dẫn } \\
\hline 5417.txt & \multicolumn{2}{|r|}{ chức, Long cử bị các câp dưới soi kĩ tữ đâu đên chân với một thái độ nghi ngờ lẫn ngạc nhiên } \\
\hline
\end{tabular}

Figure 1. The statistical relations between "đầu” and "chân"

Query head 45,528 > Positive filter (excluding KWIC) foot 264 (2.4 per million)

Page 1 of 14 Go Next I Last

JK1 bone-graft, I went all prepared, shaved from head/NN1 to foot wrapped up like a mummy, from my

JXW 'Will do.' Kay was on her feet, already heading $N v$ for the door. 'And thanks a lot.' $\langle/ p\rangle\langle p\rangle$

JY8 bones were chilled. She watched his downbent head $/ \mathrm{Vy}$ l as he examined her foot. Out of the constricting

JY5 is Adam. I don't know whether I'm on my head/NN1 or my feet with him, and it's kind of hard

JYE Already Sophie was on her feet and shaking her head /NN1 , so Joanna continued, 'lve got the directions

JYC behind the arcade she was trembling from head/NN1 to foot, racked by every emotion from

JYD behind her and stood there, shaking from head/NN1 to foot, breathing hoarsely. $\langle/ p\rangle\langle p\rangle$ The

JYD the lift, she was prickling with heat from head /NN1 to foot, intensely aware of his lean,

JYD stared at his profile. She was trembling from head /NN1 to foot . $\langle/ p\rangle\langle p\rangle$ 'Meanwhile, of course,'

JYD plane. I could see you were prickling from head /NN1 to foot with some kind of emotion towards

Figure 2. The statistical relations between "head" and "leg"

\section{Query head 45,528 > Positive filter (excluding KWIC) leg 134 ( 1.2 per million)}

\section{Page 1 of 7 Go Next I Last}

JYB garage. He had apparently sustained leg and head/NN1 injuries, and was coming in, complete with HR9 what looked like a plastic bucket on its head/NN1. Its legs - if it had legs - were covered HRB before my memory returned. Fortunately the head/NN1, neck, legs, wings, many of the larger HR8 together. Next to him, his hand grasping the head/NN1 's trouser leg, was Hasan. $\langle/ p\rangle\langle p\rangle$ 'Keep HRP tree, where, with arms wrapped around her head/NN1 and one leg twisted into the other she HRA as fast as its little legs will carry it, heading NvG in the direction of...' he snipped the final HTH shape of the nomes - two arms, two legs, a head/NN1 at the top - was a shape it associated HTY green, two legs, tyrannosaurus-featured head /NN1, and a huge tail which had inflicted most HH3 the bed shook. With no clear plan in her head/NN1, she pushed her legs out of the bed. As HHA side, so that she was forced to duck her head/NN1 past strong legs in order to see what she HUQ to be alive I moved corpses minus their heads /NN2 , legs and arms, and didn't turn ạ hair.

Figure 3. The statistical relations between "head" and "foot" 
As we can see in Figure 2 and Figure 3, the relations between the English words "head" and "leg", as well as "head" and "foot" are not as close as the relations between the Vietnamese words ““đầu” and "chân”. There are only 134 hits (1.2 per million) for the mutual occurrences between the words "head" and "leg"; and, there are only 264 hits (2.4 per million) for the mutual occurrences between the words "head" and "foot". Those numbers, even if they are combined, are still lower than that of the words "đầu" and "chân" in Vietnamese that occur together for 1142 times ( 8.8 per million). This means that the relation between the body parts in Vietnamese is closer than that in the English language.

\section{References}

[1] Baker, Paul. 2010. Sociolinguistics and Corpus Linguistics. Edinburgh: Edinburgh University Press.

[2] Bui, Khac. 1986. On the only group from the body parts of the Vietnamese people. In The Linguistic Problems of the Oriental Languages. Hanoi: VNU, pp.10 - 13.
[3] Chien, Nguyen Van. 2004. Towards the establishment of Vietnamese culture vocabulary (the study of language and culture). Hanoi: Publisher of Social Sciences.

[4] Kilgarriff, A., P. Rychlý, P. Smrž and D. Tugwell (2004). The Sketch Engine. In: Williams, G. and S. Vessier (eds.). Proceedings of the Eleventh EURALEX International Congress, EURALEX 2004. Lorient: Université De Bretagne Sud. $105-116$.

[5] Rychlý, P. 2008. A Lexicographer-Friendly Association Score. In P. Sojka and A. Horák (Eds.): Proceedings of Recent Advances in Slavonic Natural Language Processing. Brno: Masaryk University.

[6] Svartvik, J. 2007. 'Corpus Linguistics 25+ Years On.' In R. Facchineti (ed.) Corpus Linguistics 25 Years On. Amsterdam: Rodopi, 11-25.

[7] Thu, Nguyen Thi. 2005. The cultural nature of the Vietnamese language from the only extremities. In The Sixth International Symposium on pan-Asian Linguistics. Hanoi: Social Sciences Publishing House, pp.754 - 761.

[8] Trinh, Duc Hien and Do, Thi Thu. 2006.The compound word from parts of the body in Vietnamese. In Vietnam study and the Vietnamese language, Hanoi: VNU, pp.190 - 198. 